\title{
CONSTITUTIONALE
}

Volume 2 Issue 2, July-December 2021: PP: 133-144

Faculty of Law, Universitas Lampung, Bandar Lampung, Indonesia.

http://jurnal.fh.unila.ac.id/index.php/constitutionale

P-ISSN: 2723-2492 E-ISSN: 2745-9322

\section{The Polemic on Imposing Castration Sanctions against Pedophiles Perpetrators Based on the Human Right's Perspective}

\author{
Rakhmat Ubaidillah Ahror \\ Cahaya Nusa Group Ltd. Indonesia \\ Ahror.rakhmat@gmail.com
}

Submitted: Jun 3, 2021; Reviewed: Aug 9, 2021; Accepted: Nov 1, 2021

Article's Information

keywords:

Imposition of Criminal Sanction;

Castration; Pedophilia

\section{DOI}

https://doi.org/10.25041/constitution

ale.v2i2.2341

\section{Abstract}

\section{Abstract}

Sexual violence is a crime against humanity. Because, it is, closely related to human rights Cases of sexual violence caused the government to issue the idea of castration for perpetrators of sexual violence. However, this raises pros and cons in the community. The problem of this research is, how is the imposition of castration sanctions on pedophiles from a human rights perspective, and what are the supporting and inhibiting factors for implementing castration sanctions against pedophiles? The study uses a normative juridical and empirical juridical approach carried out on theoretical matters of legal principles. In contrast, the empirical approach is carried out to study the law in reality through behavioural assessments. The study results stated that the perspective of imposing castration sanctions on pedophile perpetrators also reaped the pros and cons in its implementation. Some thought that castration sanctions were quite effective if applied to perpetrators of sexual crimes to immediately provide a deterrent effect on perpetrators and break the chain of sexual crimes that developed in the community. Opinions against the castration sanction are also criticised by various groups, including human rights activists, because castration is considered a cruel 
punishment for perpetrators, and cruel punishments aim to torture the perpetrators of the crime, but this is undoubtedly related to human rights. Supporting and inhibiting factors for the implementation of castration sanctions against pedophile perpetrators. Supporting factors for the discourse of castration sanctions on perpetrators of sexual crimes against children are caused by the high number of sexual crimes in Indonesia, which has entered a dangerous stage. It was passed into Law Number 17 of 2016. The inhibiting factor is that castration sanctions are not allowed in the national criminal law system. The purpose of punishment, castration is a violation of human rights, seen from the facilities or facilities. Furthermore, there are obstacles from the executor of the castration crime, namely doctors, because it contradicts the code of ethics (KODEKI). Suggestions in this study should be in imposing criminal acts of sexual violence against children to pay attention to humane punishments without degrading and provide benefits, namely a deterrent effect.

\section{A. Introduction}

Introduction must be clear and describes the issues that are discussed in the Article. Before explaining regarding purposes, authors must provide an adequate introduction and brief literature survey to attach necessary solution/methods, and to show the main restriction of on going research. Moreover, authors must describe what must be executed from the research. In the end of the paragraph, author must close by stating a significant comment in problem identification, research purpose, and methods of the research.

Every human being has rights that cannot be violated. Human rights are inherent in the nature and life of humans; human rights already exist when a person begins to realise his position as a legal subject. The Child Protection Law or Undang-Undang Perlindungan Anak (UUPA) is a government step to increase child protection guarantees. ${ }^{1}$ Government Regulation in Lieu of Law Number 1 of 2016 was subsequently enacted into law through Law Number 17 of 2016 as a regulation to overcome problems related to the high number of cases of sexual crimes against children. ${ }^{2}$ The crime of pedophilia hurts children. The problem of pedophilia has existed since the Robot Gedek alias Siswanto case in 1996 because of his cruel act of sodomising and cruelly massacring minors. This sexual crime, of course, will indirectly involve the life of human rights that are inherent in a person from birth. In 2010 there were dozens of street children sodomized, killed, and mutilated. In 2014 the sex assaulter was arrested by the

\footnotetext{
${ }^{1}$ Aris Mohammad Ghaffar Binol Ghaf, Merry E Kalalo, and Caecilia J J Waha, "Pemenuhan Hak Anak Korban Pedofilia Di Kota Manado Menurut Perspektif Hak Asasi Manusia,” Lex Administratum 8, no. 2 (2020): 74-84, https://ejournal.unsrat.ac.id/index.php/administratum/article/view/29687/28751.

2 Tunggal S. and Nathalina Naibaho, "Penjatuhan Kebiri Kimia Bagi Pelaku Kejahatan Seksual Terhadap Anak Dalam Perspektif Falsafah Pemidanaan," Jurnal Hukum \& Pembangunan 50, no. 2 (2020): 329, https://doi.org/10.21143/jhp.vol50.no2.2594.
} 
Sukabumi Police for committing sexual violence against children, with several victims reaching 110 children. Pedophilia is a mental disorder or disorder in which a person acts by making children the object or target of sexual exploitation. ${ }^{3}$ The majority of current cases do not only involve violations and can be resolved better and professionally. ${ }^{4}$

Pedophilia is a sexual (and psychological) disorder in which a person is interested in minors. Pedophilia is a sexual deviation where a person is more attracted to small children. Pedophilia is also a sexual perversion that makes children as sexual objects that it likes. The thing that causes a person to become a pedophile is still unclear because in his research for biological factors, it has not been proven to cause pedophilia. In many cases of pedophilia, there is a link between a pedophile's past with sexual activity and the emotional (psychological) development conditions during his childhood. This is caused by the reproductive system, which is closely related to racial and class inequalities, resulting in losses. ${ }^{5}$ Research has also shown that boys who are sexually abused are more likely to be pedophiles or sex offenders. ${ }^{6}$ Based on the issues above, one example of a country suggesting several legal solutions to ensure broad, safe and efficient access to health care for this vulnerable problem, focusing on the public health crisis. $^{7}$

One of the Lecturers of Psychology at Universitas Padjadjaran stated that the factors for pedophilia are: genetic or congenital factors (internal factors) and the influence of the environment (external factors). ${ }^{8}$ According to him, these two factors can cause a person to become a pedophile. The truth is still being traced, but the environmental influence is the most dominant in shaping a person into a pedophile. In addition, he also stated that economic factors could be a driving and influential factor in this case. Overcoming this pedophile act, the government enacted Law Number 17 of 2016 concerning the stipulation of Government Regulation in Lieu of Laws Number 1 of 2016 concerning the Second Amendment to Law Number 23 of 2002 concerning Child Protection. ${ }^{9}$ The purpose and philosophy of the existence of this law are appropriate in the context of protecting children because, as the nation's successor, it has a vital role in development. This is under the provisions of the 1945 Constitution, which states that children must be protected from violence.

The ratification of the castration sanction raises two sides, namely: the protagonist and the antagonist of the imposition of the sanction. The antagonist side consists of the supporters of this law's castration sanction so that the perpetrators do not commit their crimes and bring this case down in Indonesia. On the other hand, castration is considered a violation of human rights,

\footnotetext{
${ }^{3}$ Astri Yogatama, "Muatan Pornografi Anak Pada Lingkaran Pedofilia Di Dunia Maya," Jurnal Ilmiah Scriptura 3, no. 2 (2009): 189-200, https://doi.org/10.9744/scriptura.3.2.188-200.

${ }^{4}$ Therese L. Todd and Preeti Chauhan, "Seattle Police Department and Mental Health Crises: Arrest, Emergency Detention, and Referral to Services," Journal of Criminal Justice 72, no. August 2020 (2021): 101718, https://doi.org/10.1016/j.jcrimjus.2020.101718.

5 Khiara M. Bridges, "Beyond Torts: Reproductive Wrongs And The State ," Columbia Law Review, accessed May 27, 2021, https://live-columbia-law-review.pantheonsite.io/content/beyond-torts-reproductive-wrongs-andthe-state/.

${ }^{6}$ Luthfia Ayu Azanella, "Menurut Kak Seto, Kekerasan 22 Mei 2019 Sebabkan Anak Menilai Politik Kotor," Kompas.com, 2019, https://nasional.kompas.com/read/2019/05/24/03030061/menurut-kak-seto-kekerasan-22mei-2019-sebabkan-anak-menilai-politik-kotor-?page=all.

${ }^{7}$ Vera Lúcia Raposo and Teresa Violante, “Access to Health Care by Migrants with Precarious Status During a Health Crisis: Some Insights from Portugal,” Human Rights Review, 2021, https://doi.org/10.1007/s12142-02100621-5.

8 Yuninda Tria Ningsih et al., "Dinamika Psikologis Anak Korban Pedophilia Homoseksual (Sebuah Studi Fenomenologis)," Jurnal RAP UNP 8, no. 1 (2017): 113-22, https://doi.org/10.24036/rapun.v8i1.7957.

${ }^{9}$ Laurensius Arliman S, "Kedudukan Komisi Perlindungan Anak Indonesia Sebagai State Auxiliary Bodies Dalam Sistem Hukum Ketatanegaraan Indonesia," Justitia et Pax 32, no. 2 (2017), https://doi.org/10.24002/jep.v32i2.1151.
} 
so many are against the law. ${ }^{10}$ Thus, when referring to the decision of the Constitutional Court regarding criminal sanctions that the Court has decided, an understanding can be drawn that how the inclusion of criminal sanctions in law is used as the front line (Primum remedium) in solving problems of criminal acts in Indonesia.

Several reasons underlie support for the castration law's implementation, namely: First, the castration punishment makes people think twice before committing sexual crimes against children. Second, castration does not violate human rights to have a family and have children. Third, the judge is not obliged to decide on the castration sentence. This castration sentence is an option for the judge. Fourth, to impose a castration sentence, it must be proven whether the perpetrator meets the category of perpetrators who can be sentenced to castration.

Another reason is that castration is applied in several countries in Europe and some states of the United States. Therefore, in criminal procedure, castration is not a new punishment. ${ }^{11}$ The debate is not only about human rights not to torture in giving sanctions, but also about punishment. Wimpie Pangkahila said that chemical castration is more civilised following the development of science and technology. Chemical castration is not permanent. Sexual function will return if the administration of anti-androgen substances is stopped. ${ }^{12}$ Therefore, it is natural that chemical castration injections are not proven to suppress cases of sexual crimes. The impact that needs to be followed up on by injecting or giving chemical castration pills to damage hormones or organs in the body of the sex offender is muscle function reduction, osteoporosis, reduced red blood cells and undermines organ function.

Those who reject the castration punishment (protagonist side) who view the perpetrator's rights assume that the castration sanction is a violation of human rights because sexual desire is a human right that cannot be eliminated. The Human Rights Commission of Indonesia asks that in giving punishment, both method and purpose, it is still guided by human rights. The punishment must be carried out humanely and make a person a human ready to return to socialising. ${ }^{13}$ Because looking at the notion of human rights is a fundamental right that humans are born with as a gift from God Almighty. Human rights must be respected, upheld, and protected by the state, law, government and everyone. Whereas a good citizen, the most basic rights must be protected. ${ }^{14}$

The implementation of human rights against pedophile victims in Indonesia has been regulated in preventive and repressive regulations. Its function is to protect children's human rights and provide a deterrent effect on pedophiles who make children their victims. Furthermore, if viewed from the perspective obtained by the victim, the aspect of justice for victims of sexual violence must also be considered. Some reports stated that the victim had a mental disorder; some even grew up in a deviant sexual atmosphere and lifestyle; indeed, their understanding of sexual relations would also deviate. Furthermore, if viewed from the perspective obtained by the victim, the aspect of justice for victims of sexual violence must also be considered. Some reports stated that the victim had a mental disorder. Some even grew up

${ }^{10}$ Nikmah Rosidah and Rini Fathonah, Sistem Peradilan Anak, 1st ed. (Bandar Lampung: Zam-Zam Towers, 2017), http://repository.lppm.unila.ac.id/15653/1/Buku Sistem Peradilan Pidana Anak.pdf.

11 Bestari Kumala Dewi, "Ini Efek Hukuman Kebiri Kimiawi Pada Tubuh," Kompas.com, 2016, https://health.kompas.com/read/2016/05/25/200500123/ini.efek.hukuman.kebiri.kimiawi.pada.tubuh.

12 Nur Hafizal Hasanah and Eko Soponyono, "Kebijakan Hukum Pidana Sanksi Kebiri Kimia Dalam Perspektif HAM Dan Hukum Pidana Indonesia,” Jurnal Magister Hukum Udayana (Udayana Master Law Journal) 7, no. 3 (2018): 305, https://doi.org/10.24843/jmhu.2018.v07.i03.p03.

${ }^{13}$ Liliana Listiawatie, "Penjatuhan Hukuman Kebiri Kepada Para Pelaku Kejahatan Seksual Terhadap Anak Dibawah Umur," Kertha Wicara 6, no. $4 \quad$ (2017): https://ojs.unud.ac.id/index.php/kerthawicara/article/download/34021/20508.

14 Juan Moreno Haines, "To Act Like a Democracy," UCLA Law Review, 2021, 88-96, https://searchworks.stanford.edu/articles/edsglt_edsgcl.664859528. 
in a deviant sexual atmosphere and lifestyle. Indeed their understanding of sexual relations would also deviate..$^{15}$

Geiser said victims of pedophilia tend to experience acute trauma. Overshadowed by the bleak future that will be faced, and for those who cannot bear the burden, some even choose to commit suicide. Human rights should not be the reason for imposing severe punishment on perpetrators because the perpetrators themselves have violated human rights. And human rights themselves does not mean that a person can do as he pleases, but the rights of others also limit his human rights. ${ }^{16}$

The castration sentence is set to hope that the perpetrators of this sexual violence will not repeat their actions. However, this discourse in society raises pros and cons. ${ }^{17}$ The emergence of the pros and cons and the law's socialisation related to castration sanctions is not yet apparent. Many people do not understand the castration sanction law and its impact in terms of social, cultural, and religion. Some agree with the provision of punishment in the form of castration sanctions, provided that it must be right on target and not misused for unilateral interests. Based on the description, the problems are:

1) What is the perspective of imposing castration sanctions on pedophile perpetrators based on human rights?

2) What are the supporting and inhibiting factors for castration sanctions in the implementation against pedophiles?

\section{B. Discussion}

\section{Perspective of Imposing Castraction Sanction on Pedophile Prepertrators Based on Human Rights}

Sentencing is a process in the criminal justice system to impose a crime for the perpetrator of a crime. Researchers analysed the description of the imposition of castration sanctions that criminal law is not necessary for regulating people's lives but only as an alternative to existing regulatory instruments. ${ }^{18}$ However, behind the imposition of these sanctions, the fulfilment of human rights for victims of pedophilia cannot be separated from protection because the laws and regulations guarantee to protect and fulfil the principles of rights due to victims of sexual violence are available in Indonesia. The perpetrators usually exploit through coercion and indicate what will be identified. ${ }^{19}$

Criminal law should be placed as the last instrument (ultimum remedium). Therefore the use of criminal law to regulate people's lives is not a necessity but only one alternative to community regulation. ${ }^{20}$ Punishment can be interpreted as punishment. Sentencing is also interpreted as a stage in imposing criminal sanctions. Castration sanctions, when examined

\footnotetext{
${ }^{15}$ Pusat Penelitian dan Pengembangan Humaniora dan Manajemen Kesehatan et al., "Pedofilia Sebagai Ancaman Tersembunyi Bagi Anak Pedophilia As A Hidden Threat Of Children. Yurika Fauzia Wardhani Alit Kurniasari," Ejournal.Kemsos.Go.Id, vol. 2 (Kesejahteraan Sosial), accessed January 21, 2021, www.kompasiana.com/lizanoor/edan-kasus-.

${ }^{16}$ Bagong Suyanto, Masalah Sosial Anak (Jakarta: Kencana, 2010).

${ }^{17}$ Nuzul Qur'aini Mardiya, "Penerapan Hukuman Kebiri Kimia Bagi Pelaku Kekerasan Seksual Implementation of Chemical Castration," Jurnal Konstitusi $14, \quad$ no. $1 \quad$ (2017): 18, https://jurnalkonstitusi.mkri.id/index.php/jk/article/view/14110/307.

${ }^{18}$ Efrat Even-Tzur and Uri Hadar, "Castration, Circumcision, Binding: Fathers and Agents of Socially Accepted Violence," The Psychoanalytic Quarterly 88, no. 2 (2019): 349-76, https://doi.org/10.1080/00332828.2019.1587979.

${ }^{19}$ Chrysanthi S. Leon and Corey S. Shdaimah, "Targeted Sympathy in 'Whore Court': Criminal Justice Actors' Perceptions of Prostitution Diversion Programs," Law \& Policy, April 27, 2021, https://doi.org/10.1111/lapo.12166.

20 Titis Anindyajati, Irfan Nur Rachman, and Anak Agung Dian Onita, "Konstitusionalitas Norma Sanksi Pidana Sebagai Ultimum Remedium Dalam Pembentukan Perundang-Undangan,” Jurnal Konstitusi 12, no. 4 (2016): 872, https://doi.org/10.31078/jk12410.
} 
according to Satochid Kartanegara, the purpose of punishment, there are 3 (three) theories, namely: absolute or reward/revenge, relative or purpose/objective and a combination of. ${ }^{21}$

1) The fundamental theory, the perpetrator of the crime gets a punishment commensurate with the evil he has done that has caused others to suffer. The goal is suffering must be repaid with suffering or revenge. This punishment for criminals is a must.

2) Relative theory, namely punishment aimed at prevention, both general (community) and particular (perpetrators) prevention. The castration sanction given to perpetrators of sexual crimes is intended to make the perpetrators suffer. It means that other people do not commit crimes (ne peccatur). This is per absolute punishment. In addition, sanctions aim to make other people think a thousand times to do the same thing.

3) Meanwhile, this relative theory plays an active role in the perpetrator. This castration is intended to eliminate the arousal hormone in the perpetrator. According to this relative theory, the researcher concludes that castration sanctions do not necessarily prevent perpetrators but can prevent others from committing crimes.

4) Law Number 12 of 1995 concerning Corrections states that the function of Correctional Institutions is not only as a place to punish and suffer people but aims to make correctional prisoners aware of their mistakes, improve themselves, and adapt to the community environment. 3) Combined theory, namely a fundamental theory and relativity theory. The purpose of this punishment is not only to give punishment, prevent the perpetrator from repeating his actions but also to provide protection and education for the convicts. ${ }^{22}$ The concept of this combined theory is obvious that castration sanctions are far from the goals and objectives embedded in the Permasyarkatan Law.

From the perspective of the criminal system, this castration sanction is slightly contrary to the Criminal Code. Criminal sanctions have been explicitly explained and regulated in Article 10 of the Criminal Code. There are 2 (two) forms of crime, namely, major crime and additional punishment. The death penalty, imprisonment, confinement, fines, and closure are included in the main punishment. In comparison, additional punishment consists of revocation of specific rights based on the judge's decision..$^{23}$

According to the researcher, castration sanctions do not deter perpetrators, only a form of government selfishness in punishing the perpetrators but does not see the effect on his personality and does not resolve the origin of the sexual violence. This is not under Indonesia's sentencing objectives.

\section{Supporting and Inhibiting Factors in the Implementation of Castration Sanctions against Pedophiles}

a. Supporting Factors for Implementing Castration Sanctions against Pedophiles

The supporting factor for castration sanctions for sexual crimes against children is because Indonesian Child Protection Commission or Komisi Perlindungan Anak Indonesia (KPAI) supports the high cases of sexual crimes in Indonesia. KPAI data in January-July 2013 showing that 26 per cent of the total population in Indonesia experiencing sexual violence consists of children aged 0-14 years. A total of 34,049,541 men and 32,844,509 women consisting of; physical, psychological and sexual violence in the form of rape, sodomy and sexual abuse. Reports of violence against children in January-September 2014 totalled 2,726 cases. Of this

\footnotetext{
${ }^{21}$ Satochid Kartanegara, Hukum Pidana Kumpulan Kuliah, Bagian Satu, 1st ed. (Jakarta: Balai Lektur Mahasiswa, 2001).

22 Victorio Hariara Situmorang, "Lembaga Pemasyarakatan Sebagai Bagian Dari Penegakan Hukum," Jurnal Ilmiah Kebijakan Hukum 13, no. 1 (2019): 85, https://doi.org/10.30641/kebijakan.2019.v13.85-98.

23 Aditia Arief Firmanto, "Kedudukan Pidana Kebiri Dalam Sistem Pemidanaan Di Indonesia (Pasca Dikeluarkannya PERPPU No. 1 Tahun 2016)," Jurnal Hukum Novelty 8, no. 1 (2017): 1, https://doi.org/10.26555/novelty.v8i1.a5523.
} 
amount, 58 per cent, the number of complaints of child cases in 2015 was 4,309 cases. Then in 2016, it rose to 4,622 cases and child cases in 2017, which were 4,579 cases. ${ }^{24}$

The issue of castration law, in some countries, is often debated between humanitarian considerations and the interests of protecting the victim. In India, the Indian government plans to impose forced castration on perpetrators of rape. Despite protests against being inhumane, many countries use chemical castration methods for sexual crimes.

In mid-2012, a South Korean man was sentenced to chemical castration for repeatedly sexually assaulting children. This is the first time the country has imposed chemical castration since the law took effect two years earlier. According to the rules, if he refuses or does not come according to the schedule for the injection, he can be put back in prison for seven years.

Moldova and Estonia, in 2012, passed legislation regarding the punishment of castration. Similar rules apply in many countries, including Argentina, Australia, Israel, New Zealand and Russia. At least nine American states: California, Florida, Georgia, Iowa, Louisiana, Montana, Oregon, Texas and Wisconsin also have versions of the chemical castration penalty in their legal systems. Germany is one of the countries with rules regarding the punishment of castration..$^{25}$

The National Commission for Child Protection considers that the state has not been optimal in overcoming cases of sexual violence against children. The government has not implemented it well; the government has not been able to provide a sense of security for children where the perpetrator is the person who is supposed to protect the child. Therefore, despite having a clear legal umbrella by ratifying the UN Convention on the Rights of the Child ${ }^{26}$ Child Pr asks the government to prevent and handle violent cases against children to be better in the future. ${ }^{27}$

Based on an interview with Lampung Province Child Protection Commission, the rise of sexual crimes, especially for children, makes various parties feel concerned. Therefore, the perpetrators of the legal process are given punishments that are not only the main punishment but are inserted additional punishments that can stop and destroy crimes against children with castration as an additional punishment.

According to field data from interviews with Prosecutor at the Bandar Lampung District Attorney, the government needs to revise the old child protection law because of the increasing number of sexual crimes against children. This is endangering the lives of children and damaging personal life and growth and development, causing discomfort both from peace, security, and order in society. The current legal sanctions have not maximally prevented sexual crimes against children.

The government needs to amend Law Number 23 of 2002 with Law no. 35 of 2014 concerning Child Protection. Based on these considerations, President Joko Widodo, on May 26, 2016, has signed a Government Regulation In Lieu of Law Number 1 of 2016 is now ratified as Law Number 17 of 2016 concerning the Second Amendment to Law Number 23 of 2002 concerning Child Protection.

\section{b. Factors Inhibiting the Implementation of Castration Sanctions Against Pedophiles}

\footnotetext{
${ }^{24}$ Alit Kurniasari et al., "Prevalensi Kekerasan Terhadap Anak Laki-Laki Dan Anak Perempuan Di Indonesia Prevalence of Violence Against Boys and Girls in Indonesia," Sosio Konsepsia 6, no. 3 (2018): 287-300, https://doi.org/10.33007/ska.v6i3.740.

${ }^{25}$ Wahyu Agus Hartono and Puguh Dwi Hananto, "Perbandingan Hukum Pidana Kebiri Bagi Pelaku Tindak Kekerasan Seksual Terhadap Anak Dibeberapa Negara," Jurnal.Uns.Ac.Id, vol. 2, 2013, http://news.detik.com/read/2014/05/15/143524/2583289/10/3/ini-.

${ }^{26}$ Murfiah Dewi Wulandari, Fattah Hanurawan, and Tutut Chusniyah, "Children's Knowledge and Skills Related to Self-Protection from Sexual Abuse in Central Java Indonesia," Journal of Child Sexual Abuse 29, no. 5 (2020): 499-512, https://doi.org/10.1080/10538712.2019.1703231.

27 Fitri Wahyuni, "296hukuman Kebiri Terhadap Pelaku Tindak Pidana Pemerkosaan Anak Dan Kaitannya Dengan Hak Asasi Manusia," Jurnal Hukum Dan Peradilan 6, no. 2 (2017): 279-96, https://doi.org/10.25216/jhp.6.2.2017.279-296.
} 
The application of chemical castration is a violation of human rights. The reasons for the refusal of this human rights organisation refer to several things, namely:

1) First, the punishment adopted by Indonesian law does not justify the existence of castration sanctions. In addition, many parties consider that castration is inhumane, unguided, and too vile.

2) Second, as stated in international conventions ratified in our national law, castration is a violation of human rights. It is based on the torture of the human body and mind, which automatically only aims for revenge.

3) The third is the factor of facilities or facilities; this factor is also a consideration for judges in giving criminal sanctions for castration. In addition to people against this sanction, doctors who will perform chemical castration towards the perpetrator highly disagree. The doctors disagree because the castration will violate the code of medical ethics and the Indonesian Doctors Association or Ikatan Dokter Indonesia (IDI). IDI does not allow chemical castration to be imposed because it violates the doctor's rules to heal Stipulation of Government Regulation on Child Protection. ${ }^{28}$

4) According to the Indonesian Doctors Association (IDI), Provinsi Lampung. Stated his rejection of this castration sanction because it is contrary to the code of ethics; a doctor must be a protector of life according to Article 11 of the Medical Code of Ethics. A doctor must do everything in his power to preserve the natural life of his patient and not end it. Therefore the doctor refuses to be the executor of the castration crime because it is against the code of ethics (KODEKI $)^{29}$ ).

5) According to the author, based on the description above, it is not easy to apply castration sanctions in our country because we are based on a law characterised by respect for human rights. Therefore the state is obliged to prevent all acts of cruelty, inhumane acts, and punishment categorised as torture as stated in Article 7 of Law Number 12 of 2005 concerning Ratification of the International Covenant on Civil and Political Rights. ${ }^{30}$

Indonesia is a country that has adopted a multilateral agreement from the United Nations. Consequently, Indonesia is obliged to respect, protect and fulfil the prohibition against acts of torture and inhumane treatment, as well as all forms of treatment and sanctions that demean human dignity. Castration as a sanction is a harmful action towards human rights because it violates Article 28G paragraph (1) 26, paragraph (2) 27 and Article 28I paragraph (1) of the 1945 Constitution of the Republic of Indonesia.

\section{Conclusion}

The conclusion that the writer can draw is as follows:

1. The perspective of imposing castration sanctions on pedophile actors causes pros and cons in its implementation. Opinions against the castration sanction have been criticised by various groups, including human rights activists. Some think that castration sanctions are effective enough to be applied to perpetrators of sexual crimes to deter and break the chain of sexual crimes that develop in the community. So that the castration sentence imposed on perpetrators of sexual crimes, apart from not protecting the perpetrators' human rights as regulated in the constitution, is also considered irrelevant.

2. Castration sanctions towards sexual crimes perpetrators against children have supporting factors because there are increasing cases of sexual child abuse. Moreover, Law Number

\footnotetext{
${ }^{28}$ A Yuriswanto, "Hukuman Kebiri Sebagai Pidana Tambahan Dalam Tindak Pidana Kejahatan Seksual," 2017, http://www.netralitas.com/history/read/4142/proses-kebiri-paling-ngeri-di-6-negara.

${ }^{29}$ KODEKI stands for Kode Etika Kedokteran Indonesia, Indonesian for the Indonesian Medical Code of Ethics.

${ }^{30}$ Arif Havas Oegrosoeno, "Undang-Undang Republik Indonesia Nomor 12 Tahun 2005 Tentang Pengesahan International Covenant On Civil And Political Rights (Kovenan Internasional Tentang Hak-Hak Sipil Dan Politik)," Indonesian Journal of International Law 4, no. 1 (2021), https://doi.org/10.17304/ijil.vol4.1.136.
} 
17 of 2016 concerning Child Protection is enacted as the legitimacy of castration against sexual offenders. However, there are inhibiting factors of castration sanction: In the national criminal law system or for punishment, castration is not justified. Castration violates human rights, facilities, needs thorough consideration for judges in giving criminal sanctions for castration. Lastly, there is a refusal from the Indonesian Doctors Association (IDI) to inject pedophiles with chemicals because it is against the code of ethics (KODEKI).

\section{Bibliography}

\section{A. Journal}

Agus Hartono, Wahyu, and Puguh Dwi Hananto. "Perbandingan Hukum Pidana Kebiri Bagi Pelaku Tindak Kekerasan Seksual Terhadap Anak Dibeberapa Negara.” Jurnal.Uns.Ac.Id. Vol. 2, 2013. http://news.detik.com/read/2014/05/15/143524/2583289/10/3/ini-.

Anindyajati, Titis, Irfan Nur Rachman, and Anak Agung Dian Onita. "Konstitusionalitas Norma Sanksi Pidana Sebagai Ultimum Remedium Dalam Pembentukan PerundangUndangan.” Jurnal Konstitusi 12, no. 4 (2016): 872. https://doi.org/10.31078/jk12410.

Arliman S, Laurensius. "Kedudukan Komisi Perlindungan Anak Indonesia Sebagai State Auxiliary Bodies Dalam Sistem Hukum Ketatanegaraan Indonesia." Justitia et Pax 32, no. 2 (2017). https://doi.org/10.24002/jep.v32i2.1151.

Even-Tzur, Efrat, and Uri Hadar. "Castration, Circumcision, Binding: Fathers and Agents of Socially Accepted Violence." The Psychoanalytic Quarterly 88, no. 2 (2019): 349-76. https://doi.org/10.1080/00332828.2019.1587979.

Firmanto, Aditia Arief. "Kedudukan Pidana Kebiri Dalam Sistem Pemidanaan Di Indonesia (Pasca Dikeluarkannya PERPPU No. 1 Tahun 2016)." Jurnal Hukum Novelty 8, no. 1 (2017): 1. https://doi.org/10.26555/novelty.v8i1.a5523.

Ghaf, Aris Mohammad Ghaffar Binol, Merry E Kalalo, and Caecilia J J Waha. "Pemenuhan Hak Anak Korban Pedofilia Di Kota Manado Menurut Perspektif Hak Asasi Manusia." Lex Administratum 8, no. $\quad 2 \quad$ (2020): https://ejournal.unsrat.ac.id/index.php/administratum/article/view/29687/28751.

Haines, Juan Moreno. "To Act Like a Democracy." UCLA Law Review, 2021, 88-96. https://searchworks.stanford.edu/articles/edsglt_edsgcl.664859528.

Hasanah, Nur Hafizal, and Eko Soponyono. "Kebijakan Hukum Pidana Sanksi Kebiri Kimia Dalam Perspektif HAM Dan Hukum Pidana Indonesia." Jurnal Magister Hukum Udayana (Udayana Master Law Journal) 7, no. $3 \quad$ (2018): 305. https://doi.org/10.24843/jmhu.2018.v07.i03.p03.

Kurniasari, Alit, Nurdin Widodo, Badrun Susantyo, and Yanuar F Wismayanti dan Irmayani. "Prevalensi Kekerasan Terhadap Anak Laki-Laki Dan Anak Perempuan Di Indonesia Prevalence of Violence Against Boys and Girls in Indonesia." Sosio Konsepsia 6, no. 3 (2018): 287-300. https://doi.org/10.33007/ska.v6i3.740.

Leon, Chrysanthi S., and Corey S. Shdaimah. "Targeted Sympathy in 'Whore Court': Criminal Justice Actors' Perceptions of Prostitution Diversion Programs." Law \& Policy, April 27, 2021. https://doi.org/10.1111/lapo.12166.

Listiawatie, Liliana. "Penjatuhan Hukuman Kebiri Kepada Para Pelaku Kejahatan Seksual Terhadap Anak Dibawah Umur." Kertha Wicara 6, no. 4 (2017): 1-15. https://ojs.unud.ac.id/index.php/kerthawicara/article/download/34021/20508.

Mardiya, Nuzul Qur'aini. "Penerapan Hukuman Kebiri Kimia Bagi Pelaku Kekerasan Seksual Implementation of Chemical Castration." Jurnal Konstitusi 14, no. 1 (2017): 18. https://jurnalkonstitusi.mkri.id/index.php/jk/article/view/14110/307.

Ningsih, Yuninda Tria, Duryati, Vanisa Afriona, and Thesa Dwi Djafar. "Dinamika Psikologis Anak Korban Pedophilia Homoseksual (Sebuah Studi Fenomenologis).” Jurnal RAP UNP 
8, no. 1 (2017): 113-22. https://doi.org/10.24036/rapun.v8i1.7957.

Oegrosoeno, Arif Havas. "Undang-Undang Republik Indonesia Nomor 12 Tahun 2005 Tentang

Pengesahan International Covenant On Civil And Political Rights (Kovenan Internasional Tentang Hak-Hak Sipil Dan Politik)." Indonesian Journal of International Law 4, no. 1 (2021). https://doi.org/10.17304/ijil.vol4.1.136.

Penelitian dan Pengembangan Humaniora dan Manajemen Kesehatan, Pusat, Kementerian RI Kesehatan J1, Pusat Penelitian dan Pengembangan Kesejahteraan Sosial, Kementerian RI Sosial J1 Dewi Sartika No, and Cawang Jakarta Timur. "Pedofilia Sebagai Ancaman Tersembunyi Bagi Anak Pedophilia As A Hidden Threat Of Children. Yurika Fauzia Wardhani Alit Kurniasari." Ejournal.Kemsos.Go.Id. Vol. 2. Kesejahteraan Sosial. Accessed January 21, 2021. www.kompasiana.com/lizanoor/edan-kasus-.

Raposo, Vera Lúcia, and Teresa Violante. "Access to Health Care by Migrants with Precarious Status During a Health Crisis: Some Insights from Portugal." Human Rights Review, 2021. https://doi.org/10.1007/s12142-021-00621-5.

S., Tunggal, and Nathalina Naibaho. "Penjatuhan Kebiri Kimia Bagi Pelaku Kejahatan Seksual Terhadap Anak Dalam Perspektif Falsafah Pemidanaan.” Jurnal Hukum \& Pembangunan 50, no. 2 (2020): 329. https://doi.org/10.21143/jhp.vol50.no2.2594.

Situmorang, Victorio Hariara. "Lembaga Pemasyarakatan Sebagai Bagian Dari Penegakan Hukum." Jurnal Ilmiah Kebijakan Hukum 13, no. 1 (2019): 85. https://doi.org/10.30641/kebijakan.2019.v13.85-98.

Todd, Therese L., and Preeti Chauhan. "Seattle Police Department and Mental Health Crises: Arrest, Emergency Detention, and Referral to Services." Journal of Criminal Justice 72, no. August 2020 (2021): 101718. https://doi.org/10.1016/j.jcrimjus.2020.101718.

Wahyuni, Fitri. "296hukuman Kebiri Terhadap Pelaku Tindak Pidana Pemerkosaan Anak Dan Kaitannya Dengan Hak Asasi Manusia.” Jurnal Hukum Dan Peradilan 6, no. 2 (2017): 279-96. https://doi.org/10.25216/jhp.6.2.2017.279-296.

Wulandari, Murfiah Dewi, Fattah Hanurawan, and Tutut Chusniyah. "Children's Knowledge and Skills Related to Self-Protection from Sexual Abuse in Central Java Indonesia." Journal of Child Sexual Abuse 29, no. 5 (2020): 499-512. https://doi.org/10.1080/10538712.2019.1703231.

Yogatama, Astri. "Muatan Pornografi Anak Pada Lingkaran Pedofilia Di Dunia Maya." Jurnal Ilmiah Scriptura 3, no. 2 (2009): 189-200. https://doi.org/10.9744/scriptura.3.2.188-200.

\section{B. Books}

Kartanegara, Satochid. Hukum Pidana Kumpulan Kuliah, Bagian Satu. 1st ed. Jakarta: Balai Lektur Mahasiswa, 2001.

Rosidah, Nikmah, and Rini Fathonah. Sistem Peradilan Anak. 1st ed. Bandar Lampung: ZamZam Towers, 2017. http://repository.lppm.unila.ac.id/15653/1/Buku Sistem Peradilan Pidana Anak.pdf.

Suyanto, Bagong. Masalah Sosial Anak. Jakarta: Kencana, 2010.

Yuriswanto, A. "Hukuman Kebiri Sebagai Pidana Tambahan Dalam Tindak Pidana Kejahatan Seksual," 2017. http://www.netralitas.com/history/read/4142/proses-kebiri-paling-ngeridi-6-negara.

\section{Regulations}

the 1945 Constitution as a result of the 4th amendment; Law Number 8 of 1981 concerning the Criminal Code; Law Number 2 of 2002 concerning the Indonesian Police;

Law Number 16 of 2004 concerning the Indonesian Prosecutor's Office; 
Law Number 48 of 2009 concerning Judicial Powers of the Republic of Indonesia;

Law Number 35 of 2014 concerning Amendments to Law Number 23 of 2002 concerning Child Protection:

Law Number 11 of 2012 concerning the Juvenile Justice System;

Regulation in Lieu of Law Number 1 of 2016 concerning the second amendment to Law Number 23 of 2002 concerning Child Protection;

Government Regulation Number 92 of 2015 concerning amendments to Government Regulation Number 58 of 2010 concerning Implementation of the Criminal Procedure Code.

\section{Others}

Azanella, Luthfia Ayu. "Menurut Kak Seto, Kekerasan 22 Mei 2019 Sebabkan Anak Menilai Politik Kotor."

https://nasional.kompas.com/read/2019/05/24/03030061/menurut-kak-seto-kekerasan22-mei-2019-sebabkan-anak-menilai-politik-kotor-?page=all.

Choiriah, Muchlisa. "Cerita Kejam Robot Gedek Dan Babe Habisi Para Bocah Karena Seks." Merdeka.com, 2015. https://www.merdeka.com/peristiwa/cerita-kejam-robot-gedek-danbabe-habisi-para-bocah-karena-seks.html.

Dewi, Bestari Kumala. "Ini Efek Hukuman Kebiri Kimiawi Pada Tubuh.” Kompas.com, 2016. https://health.kompas.com/read/2016/05/25/200500123/ini.efek.hukuman.kebiri.kimiawi .pada.tubuh. 
The Polemic on...

Rakhmat Ubaidillah 